\title{
Erythrosine Adsorption from Aqueous Solution via Decorated Graphene Oxide with Magnetic Iron Oxide Nano Particles: Kinetic and Equilibrium Studies
}

\author{
Seyyed Mojtaba Mousavi, ${ }^{1,2, \star}$ Seyyed Alireza Hashemi, ${ }^{1,2, \star}$ Omid Arjmand, ${ }^{3}$ \\ Ali Mohammad Amani, ${ }^{1,2}$ Aziz Babapoor, ${ }^{4}$ MohammadAli Fateh, ${ }^{5}$ Hamed Fateh, ${ }^{6}$ \\ Fatemeh Mojoudi, ${ }^{7}$ Hossein Esmaeili ${ }^{8}$ and Sara Jahandideh ${ }^{9}$ \\ ${ }^{1}$ Department of Medical Nanotechnology, School of Advanced Medical Sciences and Technologies, Shiraz University of \\ Medical Sciences, Shiraz, Iran. \\ ${ }^{2}$ Pharmaceutical Sciences Research Center, Shiraz University of Medical Sciences, Shiraz, Iran. 71348-14336. \\ ${ }^{3}$ Department of Chemical Engineering, South Tehran Branch, Islamic Azad University, Tehran, Iran. \\ ${ }^{4}$ Department of Chemical Engineering, University of Mohaghegh Ardabili, Ardabil, Iran. \\ ${ }^{5}$ Department of Civil Engineering, Estahban Branch, Islamic Azad University, Estahban, Iran \\ ${ }^{6}$ Department of Chemical Engineering, School of Chemical and Petroleum Engineering, Shiraz University, Shiraz, Iran \\ ${ }^{7}$ Department of Environment, Faculty of Natural Resources, College of Agriculture \& Natural Resources, University of \\ Tehran, Karaj, Iran. \\ ${ }^{8}$ Department of Chemical Engineering, Bushehr Branch, Islamic Azad University, Bushehr, Iran. \\ ${ }^{9}$ Department of Chemical and Polymer Engineering, Faculty of Engineering, Yazd University, Yazd, Iran. \\ *Corresponding author: E-mail:mousavi.nano@gmail.com) and \\ (s.a.hashemi0@gmail.comorsa_hashemi@sums.ac.ir)
}

Received: 14-06-2018

\begin{abstract}
In this research, first graphene oxide (GO) was synthesized using modified Hummers method and thence via a multi-step procedure, surface of $\mathrm{GO}$ was decorated with $\mathrm{Fe}_{3} \mathrm{O}_{4}$ nanoparticles $\left(\mathrm{GO}-\mathrm{Fe}_{3} \mathrm{O}_{4}\right)$. Thereafter, developed nanoparticles were characterized using FTIR, XRD and SEM analyses and their magnetic properties confirmed using VSM analysis. Moreover, performance of the $\mathrm{GO}-\mathrm{Fe}_{3} \mathrm{O}_{4}$ for the removal and adsorption of Erythrosine dye from the aqueous solution under variable conditions including $\mathrm{pH}$, phosphate buffer solution (PBS), adsorbent content, stirring time, electrolyte concentration, solution content and temperature were examined. In this regard, for obtained solutions from the chicken slaughterhouse and hospital sewage disposal system containing 20, 50 and $70 \mathrm{mg} \mathrm{mL}^{-1}$ Erythrosine dye, GO$\mathrm{Fe}_{3} \mathrm{O}_{4}$ nanoparticles adsorbed from approximately $94 \%$ to $97 \%$ of the total dye, respectively. What is more, the highest adsorption capacity was obtained at $149.25 \mathrm{mg} / \mathrm{g}$ by means of Langmuir model. The obtained results clearly showed that $\mathrm{GO}-\mathrm{Fe}_{3} \mathrm{O}_{4}$ nanoparticles present a fabulous performance for the absorption and removal of dyes form disposal systems.
\end{abstract}

Keywords: Adsorption; dye removal rate; erythrosine; graphene oxide; iron oxide

\section{Introduction}

Erythrosine or Acid Red 51 (C.I. 45430, E127) is a xanthene class and water soluble synthetic dye that frequently use as a food colorant. ${ }^{1}$ Erythrosine is a common dye in various industries and has wide range of applications in numerous fields including cosmetics, drugs, food industry especially for biscuits, chocolate, luncheon meat, sweets and chewing gums. ${ }^{2}$ Several biodegradability evaluations on dyes revealed that azo dyes are not likely to be biodegradable under aerobic condition. ${ }^{2,3}$ In this matter, more and more studies were performed to determine the adsorption capacity and capability of natural and treated vegetal materials including peat, ${ }^{4}$ sugar cane bagasse, ${ }^{5}$ bio- 
mass, ${ }^{6}$ eucalyptus bark ${ }^{7,8}$ and other biological materials with animal sources such as chitin and chitosan. ${ }^{8}$

Erythrosine $\left(\mathrm{C}_{20} \mathrm{H}_{6} \mathrm{I}_{4} \mathrm{Na}_{2} \mathrm{O}_{5}\right)$ or 2-(6-Hydroxy-2,4,5, 7-tetraiodo-3-oxo-xanthen-9-yl) benzoic acid mixture with industrial or civil wastewater can highly affect the nature and cause severe damages to the public health, ${ }^{9}$ thereby it is very essential to detect and remove these kinds of impurities from the sewage disposal systems. However, application of multivariate analyses in adsorption studies is rather limited. ${ }^{10}$ What is more, high toxicity of Erythrosine is one of the basic reasons for many environmental studies to remove this harmful dye from wastewaters. In this case, various materials and techniques were used to minimize these kinds of impurities from wastewaters including photochemical degradation using $\mathrm{TiO}_{2}$ nanoparticles, ${ }_{1}^{11}$ biochemical degradation ${ }^{12}$ and adsorption process. ${ }^{11,13-16}$

In addition, the adsorption isotherms indicated that phenol and methylene blue presenting a better adsorption rate compared with the erythrosine dye which is attributed to the large structure and the negative charge of dye molecules. ${ }^{13}$ Generally speaking, adsorption of erythrosine by activated carbon is acceptable with a maximum capacity of $89.3 \mathrm{mg} / \mathrm{g}$ at $40{ }^{\circ} \mathrm{C}$ and $\mathrm{pH}=7$. The reported adsorption capacity is modest when compared to adsorption capacity of positively charged methylene blue (C.I. 52015). ${ }^{17}$

Magnetic nanoparticles proved to be an effective removal agent for various kinds of wastes. ${ }^{18,19}$ Herein, graphene oxide (GO) was first synthesized using modified Hummers method and then fabricated GO was enhanced via $\mathrm{Fe}_{3} \mathrm{O}_{4}$ nanoparticles to improve their magnetic permeability and absorption rate. Afterward, fabricated GO$\mathrm{Fe}_{3} \mathrm{O}_{4}$ nanoparticles were used to remove erythrosine dye from the treated deionized water, hospital and chicken slaughterhouse sewer output under variable conditions.

\section{Materials and Methods}

\section{1. Materials}

Natural graphite flakes with average particle size of $150 \mu \mathrm{m}$ and purity of $>98 \%$ were supplied from Merck. Moreover, all of required materials including concentrated sulfuric acid $\left(\mathrm{H}_{2} \mathrm{SO}_{4}\right)$ (A.R., 98\%), hydrochloric acid ( $\left.\mathrm{HCl}\right)$ (A.R., 36\%), hydrogen peroxide $\left(\mathrm{H}_{2} \mathrm{O}_{2}\right)$ (A.R., 30\%), potassium permanganate $\left(\mathrm{KMNO}_{4}\right)$ (A.R.), phosphoric acid $\left(\mathrm{H}_{3} \mathrm{PO}_{4}\right), \mathrm{FeCl}_{3} 6 \mathrm{H}_{2} \mathrm{O}, \mathrm{FeSO}_{4} 7 \mathrm{H}_{2} \mathrm{O}$, phosphate buffer solution (PBS), ammonia $\left(\mathrm{NH}_{3}\right)$, sodium hydroxide $(\mathrm{NaOH})$ and erythrosine dye were supplied by Merck.

\section{2. Preparation of Erythrosine Solution}

For preparation of erythrosine solution, first $0.1 \mathrm{~g}$ of erythrosine dye poured into a $1000 \mathrm{~mL}$ volumetric flask along with deionized water $\left(100 \mu \mathrm{g} \mathrm{mL}^{-1}\right)$ and then dissolved to reach homogenous solution. This solution was used to prepare other solutions with different concentrations.

\section{3. Preparation of Phosphate Buffer Solution (PBS)}

For preparation of (PBS), $100 \mathrm{~mL}$ phosphoric acid ( 0.1 molar) poured in a beaker and then the $\mathrm{pH}$ of the suspension was set on 7 using $\mathrm{pH}$ meter and $1 \mathrm{~mL}$ solution of sodium hydroxide and hydrochloric acid.

\section{4. Preparation of Graphene Oxide (GO)}

In this study, GO nanoparticles were fabricated using modified Hummers method. ${ }^{20,21}$ In this case, first $10 \mathrm{~g}$ graphite poured into a round-bottom flask and then $2 \mathrm{~L}$ $\mathrm{H}_{2} \mathrm{SO}_{4}$ was added to the vessel and stirred for $30 \mathrm{~min}(500$ $\mathrm{rpm}$ ) at room temperature (RT). Thence $110 \mathrm{~mL} \mathrm{H}_{3} \mathrm{PO}_{4}$ was added to the suspension, stirred for further $30 \mathrm{~min}$ ( $500 \mathrm{rpm}$ at RT) and thereafter the temperature of the suspension was decreased to less than $5{ }^{\circ} \mathrm{C}$ using ice bath. Next, $50 \mathrm{~g} \mathrm{KMnO}_{4}$ was slowly added to the suspension and stirred (500 rpm) for $30 \mathrm{~min}$. In the next step, the temperature of the suspension was smoothly increased to about $50{ }^{\circ} \mathrm{C}$ and then stirred for $(500 \mathrm{rpm}) 72 \mathrm{~h}$. Afterward, the suspension was poured in a vacuum Erlenmeyer flask and some pieces of ice cubes (made from deionized water) were poured into the flask. Thereupon, $10 \mathrm{~mL} \mathrm{H}_{2} \mathrm{O}_{2}$ was poured in the suspension very slowly and then the vacuum Erlenmeyer flask was filled with deionized water. The resulting suspension was kept without stirring for $48 \mathrm{~h}$ for further fillers sedimentation. Afterward, the suspension was filtered and washed with $\mathrm{HCl}$ for removal of metal ions, and then remained fillers on the filter paper were washed with deionized water in order to set their $\mathrm{pH}$ at 7 . Filtered and washed nanoparticles were dried for $1 \mathrm{~h}$ at $80{ }^{\circ} \mathrm{C}$ in a heating oven and thence placed in a humidity absorbing chamber for $48 \mathrm{~h}$.

\section{5. Preparation of Decorated Graphene Oxide with Iron Oxide Nanoparticles $\left(\mathrm{GO}-\mathrm{Fe}_{3} \mathrm{O}_{4}\right)$}

For the production of $\mathrm{GO}-\mathrm{Fe}_{3} \mathrm{O}_{4}$ nanoparticles, first, $3.89 \mathrm{~g} \mathrm{FeCl}_{3}$ and $4.55 \mathrm{FeSO}_{4}$ poured into $320 \mathrm{~mL}$ deionized water and stirred for $1 \mathrm{~h}$ at $80^{\circ} \mathrm{C}$. Thence, $0.0844 \mathrm{~g}$ ultrasonicated GO in $100 \mathrm{~mL}$ deionized water (at $300 \mathrm{~W}$ for 10 min) were added to the previous suspension and stirred for further $1 \mathrm{~h}$ at $80^{\circ} \mathrm{C}$. Thereafter, $40 \mathrm{~mL} \mathrm{NH}_{3}$ was slowly added to the resulting suspension and thereafter stirred for $24 \mathrm{~h}$ at $80^{\circ} \mathrm{C}$. Next, finalized suspension was vacuum filtrated and washed with deionized water to neutralize the fabricated $\mathrm{GO}-\mathrm{Fe}_{3} \mathrm{O}_{4}$ nanoparticles.

\section{6. Nanoparticles Evaluation Methods}

For evaluation of developed fillers performance for removal of erythrosine dye from aqueous solutions, first $15 \mathrm{~mL}$ erythrosine dye $\left(100 \mu \mathrm{g} \mathrm{mL}^{-1}\right)$ and $2 \mathrm{~mL}$ PBS (with 
$\mathrm{pH}=7$ ) poured into a $50 \mathrm{~mL}$ volumetric flask and then filled with deionized water. Thereafter, $0.2 \mathrm{~g}$ of $\mathrm{GO}-\mathrm{Fe}_{3} \mathrm{O}_{4}$ poured into the resulting suspension and then stirred for 2 $\mathrm{min}$ at $500 \mathrm{rpm}$. Afterward, the beaker containing the resulting suspension was put on a strong magnet for $1 \mathrm{~min}$ for sediment of $\mathrm{GO}-\mathrm{Fe}_{3} \mathrm{O}_{4}$ nanoparticles. Experimental evaluation showed that erythrosine dye has a peak at 523 $\mathrm{nm}$ in visible light region (can be seen in section.3.1). In this case, for determination of erythrosine removal rate, the adsorption rate by fillers were examined at $523 \mathrm{~nm}$ wavelength. In the final stage, the dye removal rate (\%) was calculated using the following equation: ${ }^{22}$

$$
\text { Removal }(\%)=\left(\left(C_{i}-C_{f}\right) / C_{i}\right) \times 100
$$

Where the $C_{i}$ and $\mathrm{C}_{\mathrm{f}}$ are the initial dye concentration (before reaction with GO- $-\mathrm{Fe}_{3} \mathrm{O}_{4}$ ) and the final dye concentration (after reaction with $\mathrm{GO}-\mathrm{Fe}_{3} \mathrm{O}_{4}$ ), respectively.

\section{7. Choosing the Maximum Wavelength $\left(\lambda_{\max }\right)$}

Maximum wavelength peak related to the erythrosine dye was determined via UV-vis spectroscopy in the visible-light region ranging from 400 to $700 \mathrm{~nm}$. In this matter, the maximum wavelength for the erythrosine dye was saw at $523 \mathrm{~nm}$. Therefore, the final adsorption rate by developed fillers was measured at the fixed wavelength of $523 \mathrm{~nm}$ during all processes.

\section{8. Characterization}

In order to examine developed fillers, various instruments were used including Fourier-transform infrared spectroscopy (FTIR) (Bruker model VECTOR22), X-ray diffraction (XRD) (Brucker model D8-ADVANCE), vibrating sample magnetometer (VSM), scanning electron microscope (SEM) (Tescan model VEGA3) and UV-vis Spectrophotometer (Shimadzu model UV-1800).

\section{Results and Discussions}

\section{1. Examination of Fabricated GO-Fe ${ }_{3} \mathrm{O}_{4}$ Nanoparticles}

In this section, specifications of fabricated $\mathrm{GO}-\mathrm{Fe}_{3} \mathrm{O}_{4}$ nanoparticles were evaluated using FTIR, XRD, VSM and SEM analyses. In Fig. 1 (a), FTIR results of $\mathrm{Fe}_{3} \mathrm{O}_{4}, \mathrm{GO}$ and GO- $\mathrm{Fe}_{3} \mathrm{O}_{4}$ can be seen, respectively. As can be seen in the spectrum of $\mathrm{Fe}_{3} \mathrm{O}_{4}$ (red color), peaks in region between $530-630 \mathrm{~cm}^{-1}$ are correspond to the stretching vibration mode of Fe-O. In this case, broad and strong peak at 575 $\mathrm{cm}^{-1}$ is correspond to the $\mathrm{Fe}_{3} \mathrm{O}_{4}$ and indicate the successful synthesize of $\mathrm{Fe}_{3} \mathrm{O}_{4}$ nanoparticles. ${ }^{23-25}$ Moreover, peaks at 923 and $1108 \mathrm{~cm}^{-1}$ are related to the $\mathrm{sp}^{2}$ alkene $\mathrm{C}-\mathrm{H}$ band (disubstituted-E) and stretching vibration of inplane $\mathrm{C}-\mathrm{H}$, respectively. Besides, peak with wavenumber $1616 \mathrm{~cm}^{-1}$ is belong to the $\mathrm{FeOO}^{-},{ }^{24}$ while peaks in region between $2838-2921 \mathrm{~cm}^{-1}$ are belong to the $\mathrm{C}-\mathrm{H}$ stretching vibration $\left(\mathrm{sp}^{3}\right.$ stretching of hexyl aliphatic side). Weak peaks in the region between $3500-3700 \mathrm{~cm}^{-1}$ are belong to the amine N-H. Furthermore, broad and strong peak at $3424 \mathrm{~cm}^{-1}$ is correspond to the hydroxyl functional group $(-\mathrm{OH}) .{ }^{24}$ In addition, as shown in the GO spectrum (Figure 1 (a) green color), GO was successfully synthesized with compatible functional groups including carboxyl $\left(1715 \mathrm{~cm}^{-1}\right)$, hydroxyl $\left(3398 \mathrm{~cm}^{-1}\right)$ and epoxide $\left(1057 \mathrm{~cm}^{-1}\right)$ which provide the possibility of molecular attachment between $\mathrm{GO}$ and $\mathrm{Fe}_{3} \mathrm{O}_{4}$ nanoparticles. In $\mathrm{GO}$ spectrum, peaks with wavenumbers $584,854,891,1006,1165$ and 1632 are correspond to the $\mathrm{C}=\mathrm{O}$ in amides, $\mathrm{C}-\mathrm{H}$ sp ${ }^{2}$, germinal disubstituted, vibration of a p-disubstituted phenyl group $v_{c-H}$ in plane bending), $\mathrm{C}-\mathrm{OH}$ in alcohols and $\mathrm{C}=\mathrm{C}$ bonds ( $\mathrm{sp}^{2} \mathrm{C}-\mathrm{X}$ double bonds) in aromatic ring, respectively. ${ }^{18}$

a)

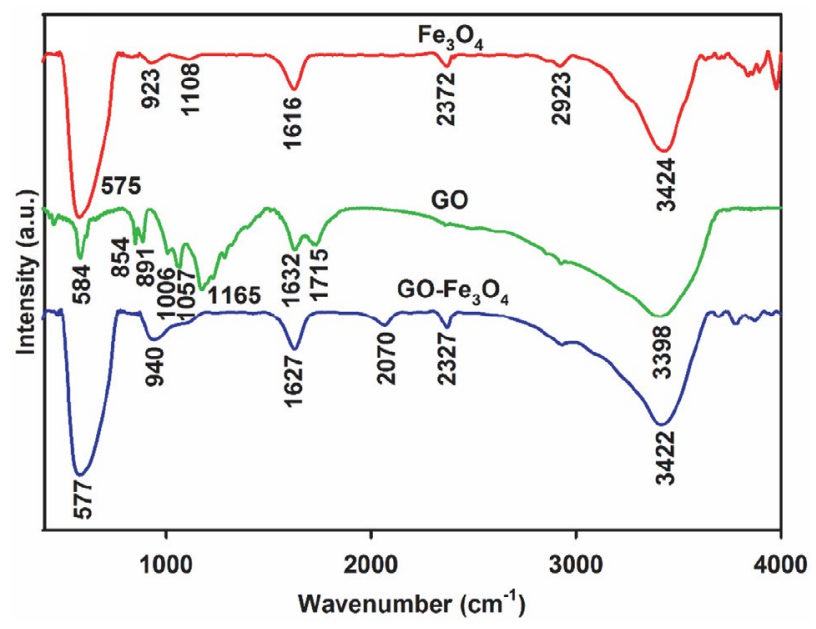

b)

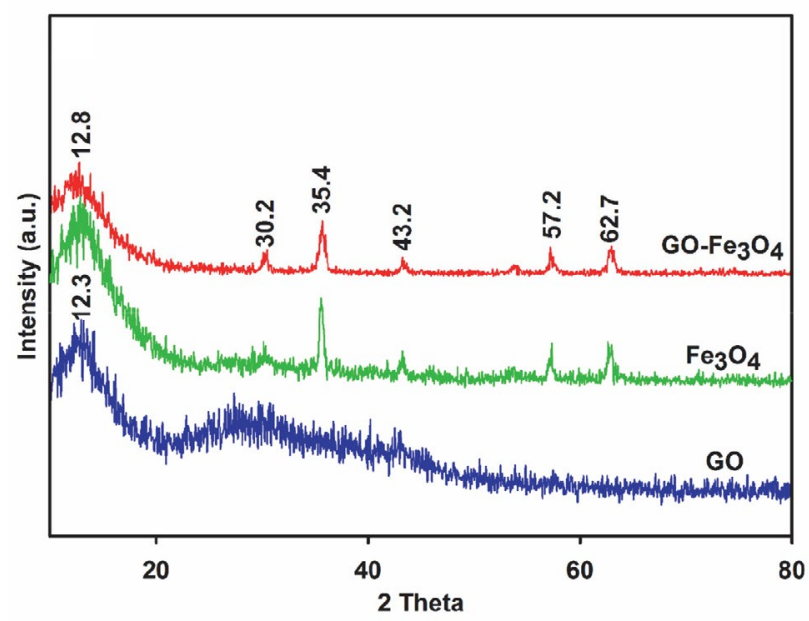

Figure 1. (a) FTIR and (b) XRD results of $\mathrm{Fe}_{3} \mathrm{O}_{4}$, GO and GO$\mathrm{Fe}_{3} \mathrm{O}_{4}$. 
In Fig. 1 (a) (blue color), it can be seen that GO$\mathrm{Fe}_{3} \mathrm{O}_{4}$ was successfully synthesized. In this case, strong peak at $577 \mathrm{~cm}^{-1}$, which known as the fingerprint of $\mathrm{Fe}_{3} \mathrm{O}_{4},{ }^{23-25}$ along with peak at $1627 \mathrm{~cm}^{-1}$ that correspond to the $\mathrm{FeOO}^{-},{ }^{24}$ clarify the molecular attachment of $\mathrm{Fe}_{3} \mathrm{O}_{4}$ nanoparticles on the surface of GO. Furthermore, peaks with wavenumbers 940 and $3422 \mathrm{~cm}^{-1}$ are correspond to the $\mathrm{sp}^{2}$ alkene $\mathrm{C}-\mathrm{H}$ bond and hydroxyl functional group, respectively. Appearance of peaks at 577 and $1627 \mathrm{~cm}^{-1}$ along with disappearance of carboxyl and epoxide functional groups related peaks and decrease in the intensity of hydroxyl functional group in the $\mathrm{GO}-\mathrm{Fe}_{3} \mathrm{O}_{4}$ spectrum compared with $\mathrm{GO}$ and $\mathrm{Fe}_{3} \mathrm{O}_{4}$ spectrums, confirm whether the successful decoration of $\mathrm{GO}$ with $\mathrm{Fe}_{3} \mathrm{O}_{4}$ or molecular attachment of $\mathrm{Fe}_{3} \mathrm{O}_{4}$ on the surface of GO. In fact, decrease in the intensity of hydroxyl functional group and disappearance of carboxyl and epoxide functional groups clarify the interaction between functional groups of $\mathrm{GO}$ and $\mathrm{Fe}_{3} \mathrm{O}_{4}$.

In addition, in Fig. 1 (b), XRD results for $\mathrm{GO}, \mathrm{Fe}_{3} \mathrm{O}_{4}$ and $\mathrm{GO}-\mathrm{Fe}_{3} \mathrm{O}_{4}$ can be seen, respectively. As can be seen in this figure, $\mathrm{XRD}$ results shows that $\mathrm{GO}$ nanoparticles were successfully synthesized, while they show a peak (2O) around 12.3 which is correspond to the inter planer spacing of $0.84 \mathrm{~nm} .{ }^{26}$ On the other hand, in Fig. 1 (b) it can be seen that related XRD peaks for $\mathrm{Fe}_{3} \mathrm{O}_{4}$ and $\mathrm{GO}-\mathrm{Fe}_{3} \mathrm{O}_{4}$ are the same as each other, which are in accord of previous studies outcomes. ${ }^{26-28}$
In this regard, the diffraction peaks $(2 \Theta)$ at 30.2 , $35.4,43.2,57.2$ and 62.7 are correspond to the (111), (220), (311), (222), (400) and (422) planes of the $\mathrm{Fe}_{3} \mathrm{O}_{4}$ which have appeared in the spectrum of $\mathrm{GO}-\mathrm{Fe}_{3} \mathrm{O}_{4}$ and it is correspond with pure spinel $\mathrm{Fe}_{3} \mathrm{O}_{4}$ (no. 89-3854) (Xie et al. 2012; Hur et al. 2015; Ai et al. 2011). Moreover, decoration of GO with $\mathrm{Fe}_{3} \mathrm{O}_{4}$ nanoparticles did not cause any shifts in diffraction peaks. Achieved data from FTIR and XRD analyses clearly confirmed the successful modification of $\mathrm{GO}$ flakes with $\mathrm{Fe}_{3} \mathrm{O}_{4}$ nanoparticles.

What is more, In Fig. 2 (a), VSM magnetization of GO$\mathrm{Fe}_{3} \mathrm{O}_{4}$ nanoparticles can be seen. As can be seen in this figure, hysteresis loop of developed $\mathrm{GO}-\mathrm{Fe}_{3} \mathrm{O}_{4}$ is S-like curve, while its specific saturation magnetization $\left(\mathrm{M}_{\mathrm{S}}\right)$, remanence $\left(\mathrm{M}_{\mathrm{r}}\right)$, coercivity $\left(\mathrm{H}_{\mathrm{c}}\right)$, squareness ratio $\left(\mathrm{SQR}=\mathrm{M}_{\mathrm{r}} / \mathrm{M}_{\mathrm{s}}\right)$ and switching field distribution $\left(\mathrm{SDF}=\Delta \mathrm{H} / \mathrm{H}_{\mathrm{c}}\right)$ are $51.84 \mathrm{emu} \mathrm{g}^{-1}$, $14.81 \mathrm{emu} \mathrm{g}^{-1}, 176.4 \mathrm{Oe}, 0.285$ and 1.945 , respectively. Additionally, $\mathrm{GO}-\mathrm{Fe}_{3} \mathrm{O}_{4}$ is an intermediate magnetic material with anisotropic behavior, which has presented fantastic magnetic performance. In fact, $\mathrm{GO}-\mathrm{Fe}_{3} \mathrm{O}_{4}$ can improve the removal rate of the erythrosine dye from any kind of wastewater due to its intermediate magnetic properties. Furthermore, In Fig. 2 (b), (c) and (d), SEM images of GO, GO$\mathrm{Fe}_{3} \mathrm{O}_{4}$ and $\mathrm{Fe}_{3} \mathrm{O}_{4}$ can be seen, respectively. As can be seen in these figures, $\mathrm{GO}$ nanoparticles were successfully decorated and modified with magnetic $\mathrm{Fe}_{3} \mathrm{O}_{4}$ nanoparticles which is in accord with obtained data from FTIR and XRD analyses.
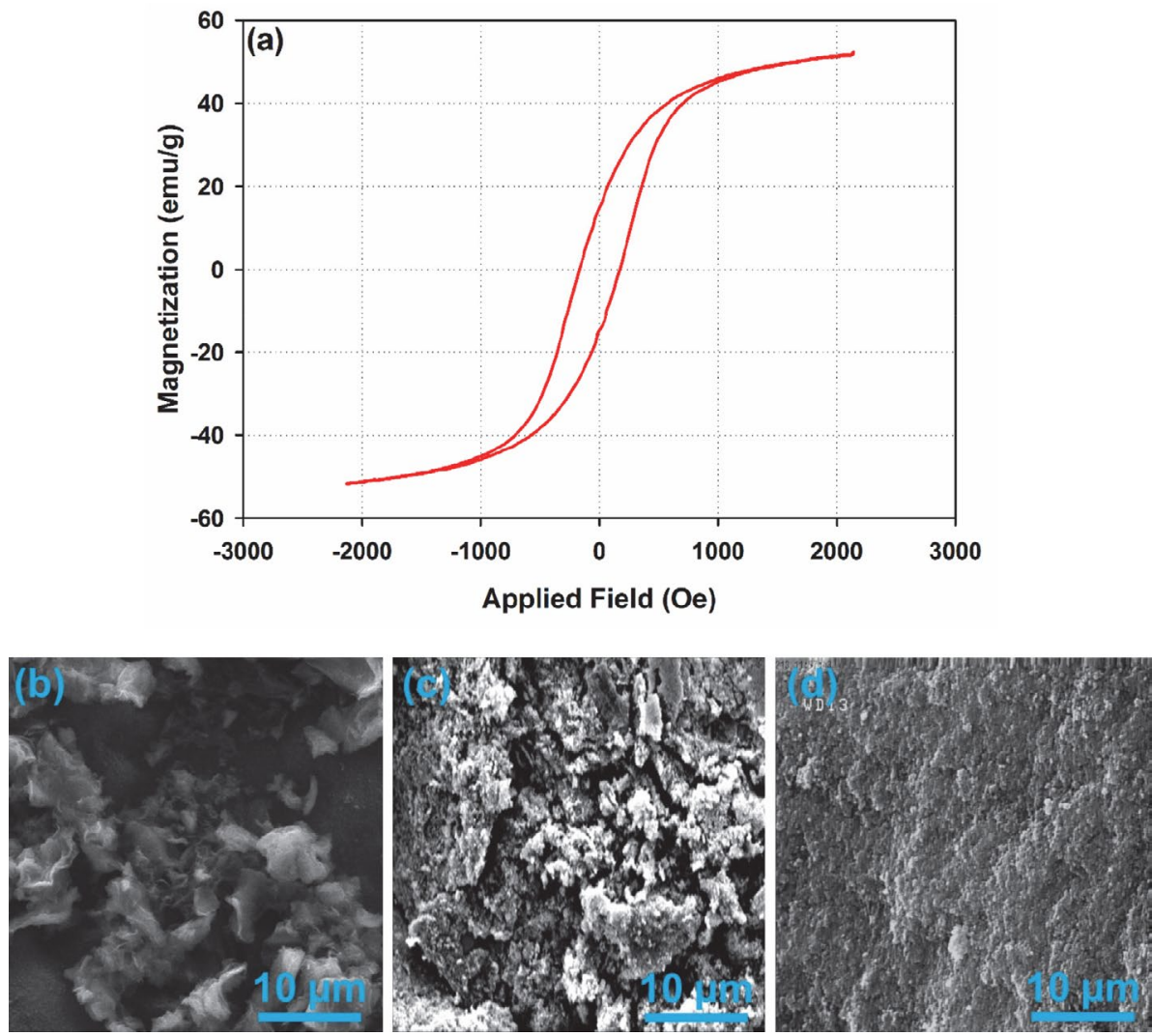

Figure 2. (a) VSM results for GO- $\mathrm{Fe}_{3} \mathrm{O}_{4}$ nanoparticles and SEM images of (b) GO, (c) GO- $\mathrm{Fe}_{3} \mathrm{O}_{4}$ and (d) $\mathrm{Fe}_{3} \mathrm{O}_{4}$. 


\section{2. Examination of Erythrosine Dye Removal Rate}

\section{2. 1. Effect of pH on the Erythrosine Removal Rate}

Solution $\mathrm{pH}$ is one of the most important factors on the adsorption of pollutants. In this section, the effect of variable $\mathrm{pH}$ (ranging from 3-9) on the dye removal rate and final adsorption rate of Erythrosine dye from aqueous solution were examined. In this case, the final $\mathrm{pH}$ of the solution containing Erythrosine dye was fixed and regulated via addition of hydrochloric acid and sodium hydroxide. Moreover, in order to achieve the optimal $\mathrm{pH}, 15 \mathrm{~mL}$ of Erythrosine dye $\left(100 \mu \mathrm{g} \mathrm{mL}^{-1}\right)$ was poured into a $50 \mathrm{~mL}$ volumetric flasks and thence variable volumes of a solution containing hydrochloric acid and sodium hydroxide was added to the primary solution to regulate the $\mathrm{pH}$ on the

a)

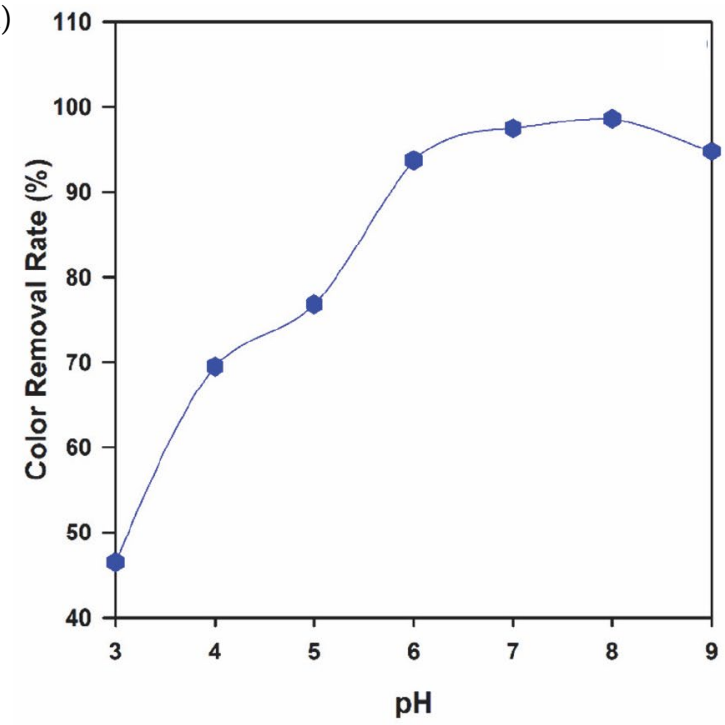

c)

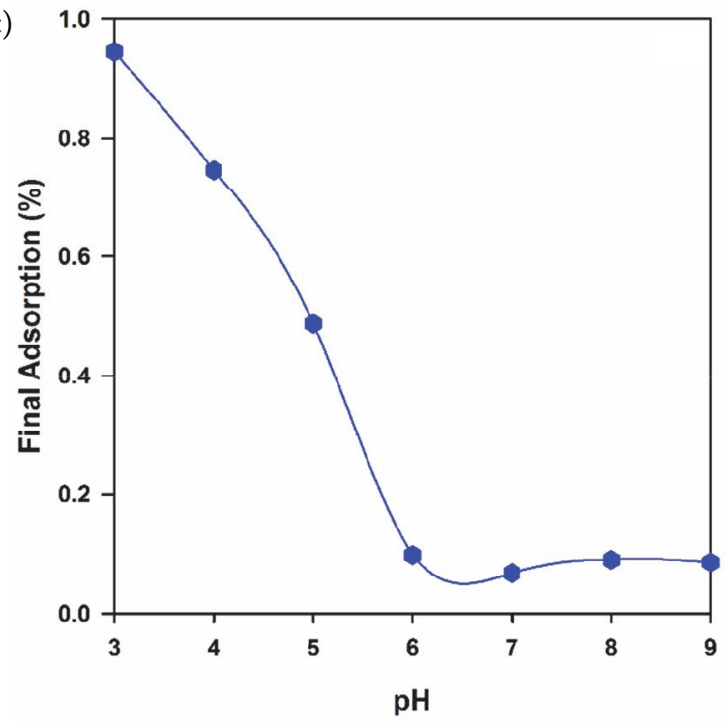

desirable value. Afterward, $0.2 \mathrm{~g}$ of $\mathrm{GO}-\mathrm{Fe}_{3} \mathrm{O}_{4}$ was poured into the dye solution and stirred for $2 \mathrm{~min}(500 \mathrm{rpm})$ and then placed on a strong magnet for further sediment of fillers and adsorption of the dye by magnetic fillers. Thereafter, the level of dye adsorption rate was measured at wavelength of $523 \mathrm{~nm}$. In Fig. 3 (a) and (c) the effect of variable $\mathrm{pH}$ on the dye removal rate and final adsorption of Erythrosine dye can be seen, respectively. As can be seen in this figure, increase in the $\mathrm{pH}$ of the suspension and neutralization of the suspension can enhance the dye removal rate, thus $\mathrm{pH}=7$ was selected as the optimal $\mathrm{pH}$ for the solution.

\section{2. 2. Effect of PBS Content on the Erythrosine Removal Rate}

In this section, effect of variable buffer content on the removal rate and final adsorption of the dye was eval-

b)

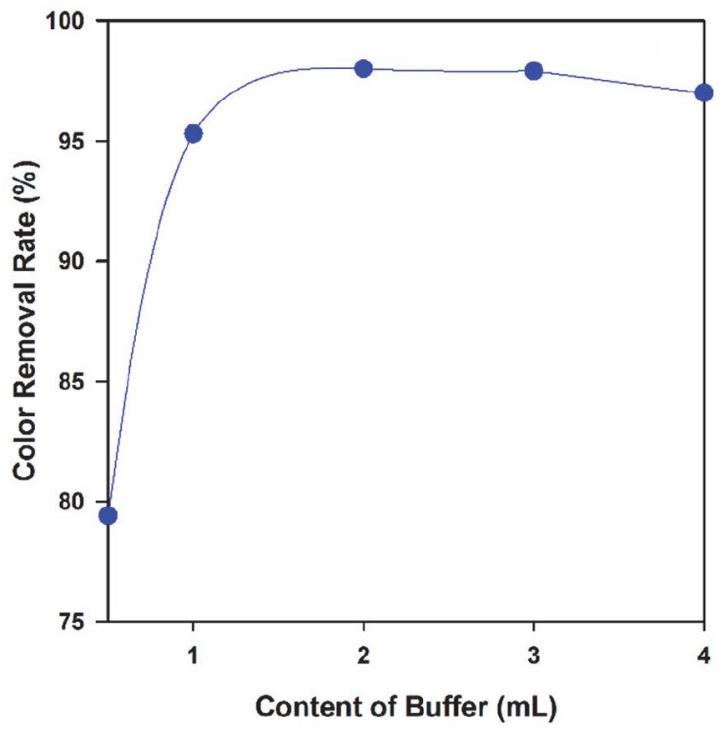

d)

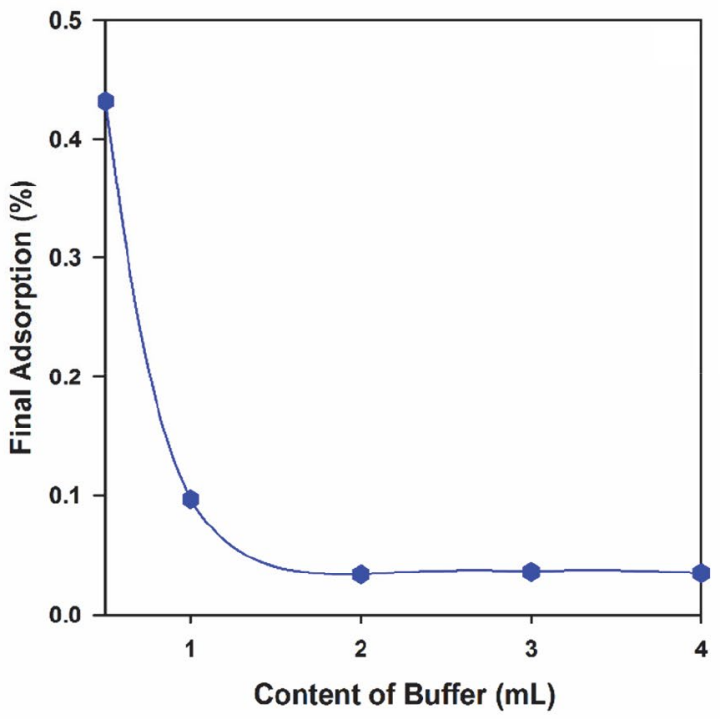

Figure 3. (a) The effect of variable $\mathrm{pH}$ and (b) PBS volume on the dye removal rate; and (c) the effect of variable pH and (d) PBS volume on the final adsorption rate of Erythrosine dye. 
uated. In this regard, various volumes of PBS were added to the solution containing Erythrosine dye (at $\mathrm{pH}=7$ ), while the dye removal rate and final adsorption were recorded at $523 \mathrm{~nm}$ wavelength. Figure 3 (b) and (d), show the dye removal rate and final adsorption of the dye at various contents of PBS. Obtained results revealed that increase in the content of PBS up to $2 \mathrm{~mL}$ can lead to significant improvement in the dye removal rate, while the dye removal rate was levelled off at contents more than 2 $\mathrm{mL}$. Therefore, $2 \mathrm{~mL}$ PBS was considered as the optimal buffer volume.

\section{2. 3. Effect of GO- $\mathrm{Fe}_{3} \mathrm{O}_{4}$ Content on the Erythrosine Removal Rate}

In this section, effect of adsorbent content on the dye removal rate and final adsorption rate of dye was ex-

a)

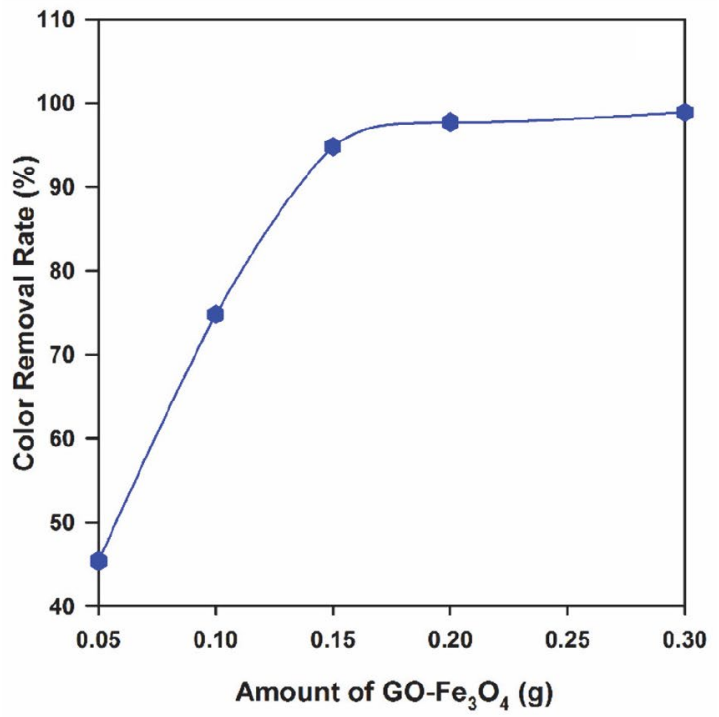

c)

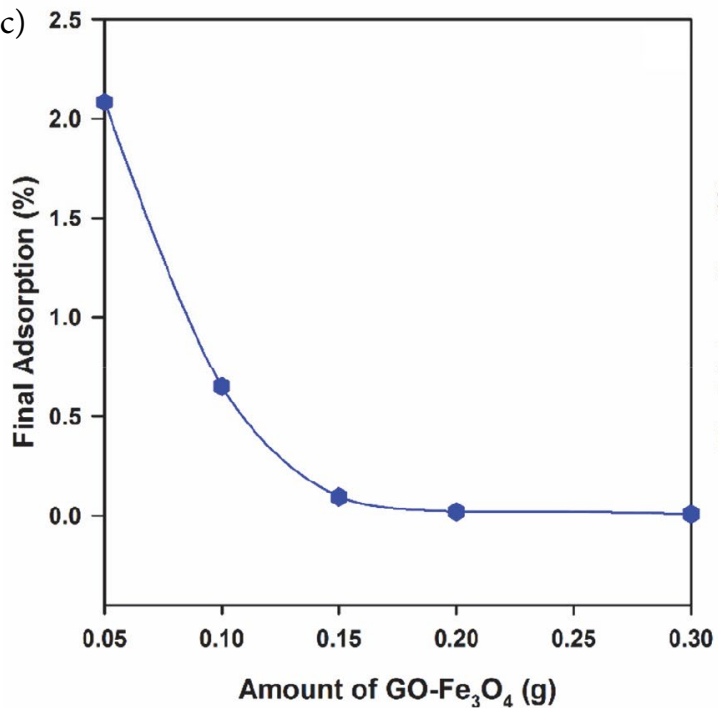

amined. In this regard, $15 \mathrm{~mL}$ of Erythrosine dye $(100 \mu \mathrm{g}$ $\mathrm{mL}^{-1}$ ) along with $2 \mathrm{~mL}$ PBS (with $\mathrm{pH}=7$ ) were poured into a $50 \mathrm{~mL}$ volumetric flask and then the flask was filled with deionized water. Afterward, same amount of the resulting suspension was poured into six different beakers and various amount of $\mathrm{GO}-\mathrm{Fe}_{3} \mathrm{O}_{4}$ ranging from 0.05 to $0.3 \mathrm{~g}$ was added to the suspension and sonicated for $2 \mathrm{~min}$ (500 rpm). Then, the resulting suspension was placed on a strong magnet for further $1 \mathrm{~min}$ and after fillers sediment, the dye removal rate and final adsorption rate of Erythrosine dye were measured at wavelength of $523 \mathrm{~nm}$. In Fig. 4 (a) and (c), the effect of filler content on the dye removal rate and final adsorption can be seen, respectively. Obtained results showed that increase in the content of fillers up to $0.2 \mathrm{~g}$ can lead to significant improvement in the dye removal rate, while the level of removal rate was levelled off in contents more than $0.2 \mathrm{~g}$, thereby $0.2 \mathrm{~g} \mathrm{GO}$ -

b)

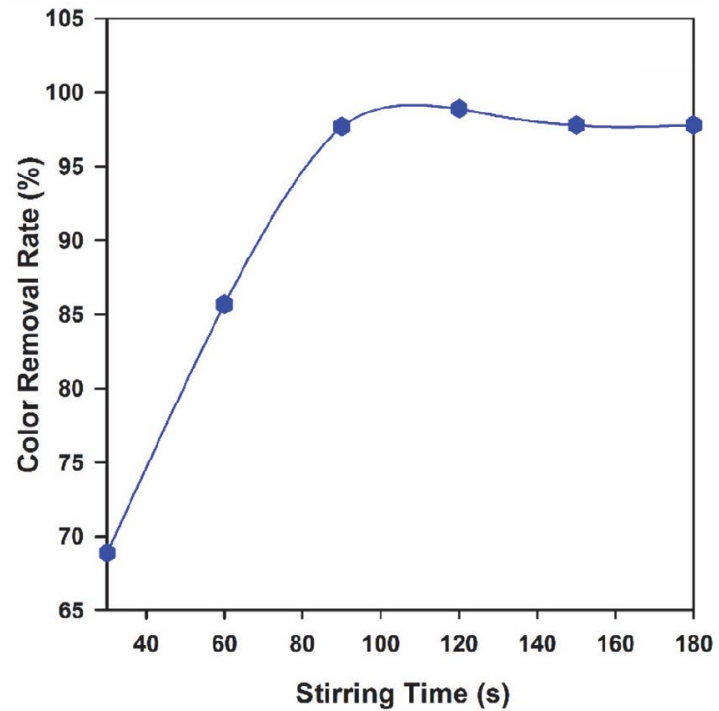

d)

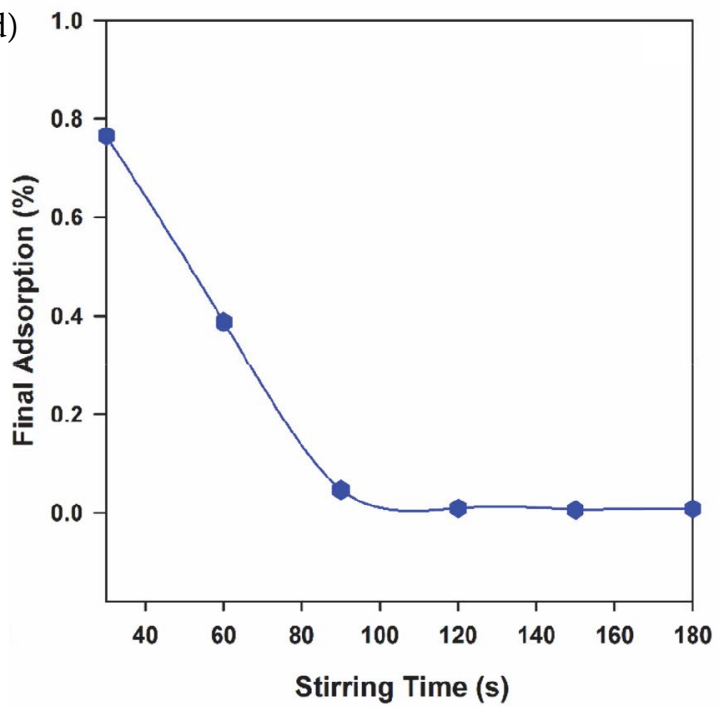

Figure 4. The effect of (a) magnetite filler content and (b) stirring time on the color removal rate; and the effect of (c) magnetite filler content and (d) stirring time on the final adsorption of Erythrosine dye. 
$\mathrm{Fe}_{3} \mathrm{O}_{4}$ was considered as the optimal amount of adsorbent.

\section{2. 4. Effect of Stirring Time on the Erythrosine Removal Rate}

In this section, effect of diverse mixing times (40$180 \mathrm{~s}$ ) on the dye removal rate and final adsorption of dye at wavelength of $523 \mathrm{~nm}$ were examined. In this case, produced solution containing $2 \mathrm{~mL} \mathrm{PBS}(\mathrm{pH}=7)$ along with $0.2 \mathrm{~g} \mathrm{GO}-\mathrm{Fe}_{3} \mathrm{O}_{4}$ was stirred at different selected times. In Fig. 4, obtained results can be seen, which parts (b) and (d) showing the dye removal rate and final adsorption of dye from aqueous solution. Achieved results showed that by increase in the stirring time up to $2 \mathrm{~min}$, the final dye removal rate remains at balanced amount. Therefore, $2 \mathrm{~min}$ stirring was considered as the optimal mixing time.

a)

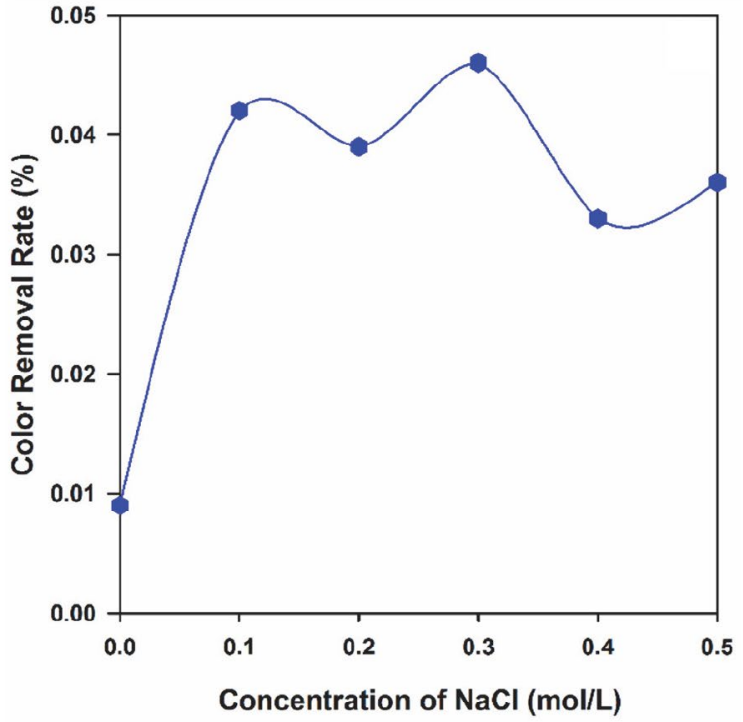

c)

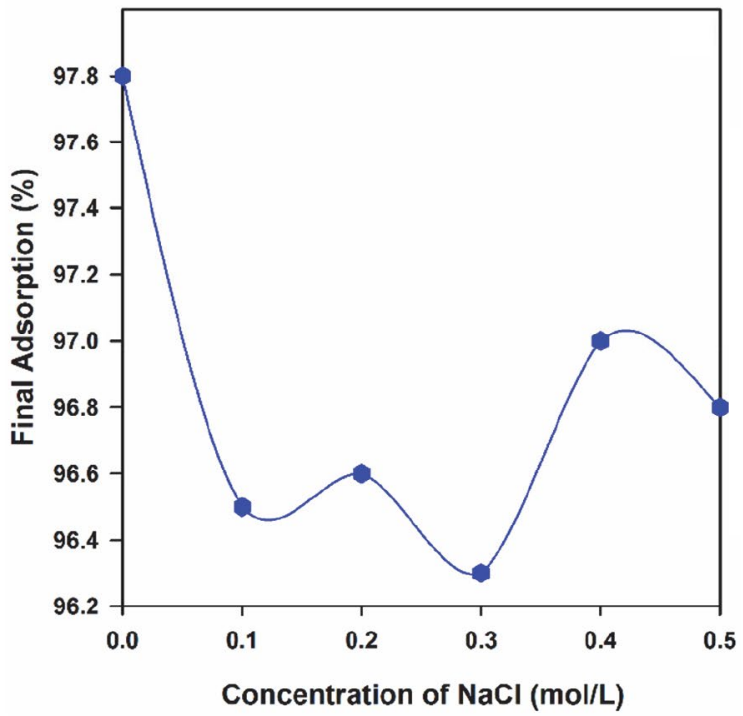

\section{2. 5. Effect of Electrolyte Concentration} on the Erythrosine Removal Rate

In this section, the effect of the electrolyte concentration on the dye removal rate and final adsorption of dye at wavelength of $523 \mathrm{~nm}$ was evaluated. For this matter, 15 $\mathrm{mL}$ of Erythrosine solution $\left(100 \mu \mathrm{g} \mathrm{mL}^{-1}\right)$ along with $2 \mathrm{~mL}$ PBS ( $\mathrm{pH}=7)$ and variable amount of 1 molar sodium chloride were poured into a $50 \mathrm{~mL}$ volumetric flask and afterward the flask was filled with deionized water. Thence, $0.2 \mathrm{~g} \mathrm{GO}-\mathrm{Fe}_{3} \mathrm{O}_{4}$ was added to the suspensions containing various concentrations of electrolyte. Then, each beaker was placed on a strong magnet for $1 \mathrm{~min}$ and after sediment of fillers, the dye removal rate and final adsorption were calculated at wavelength of $523 \mathrm{~nm}$, which can be seen in Figure 5 (a) and (c), respectively. Achieved results revealed that increase in the concentration of electrolyte has negligible effects on the dye removal rate and final ad-
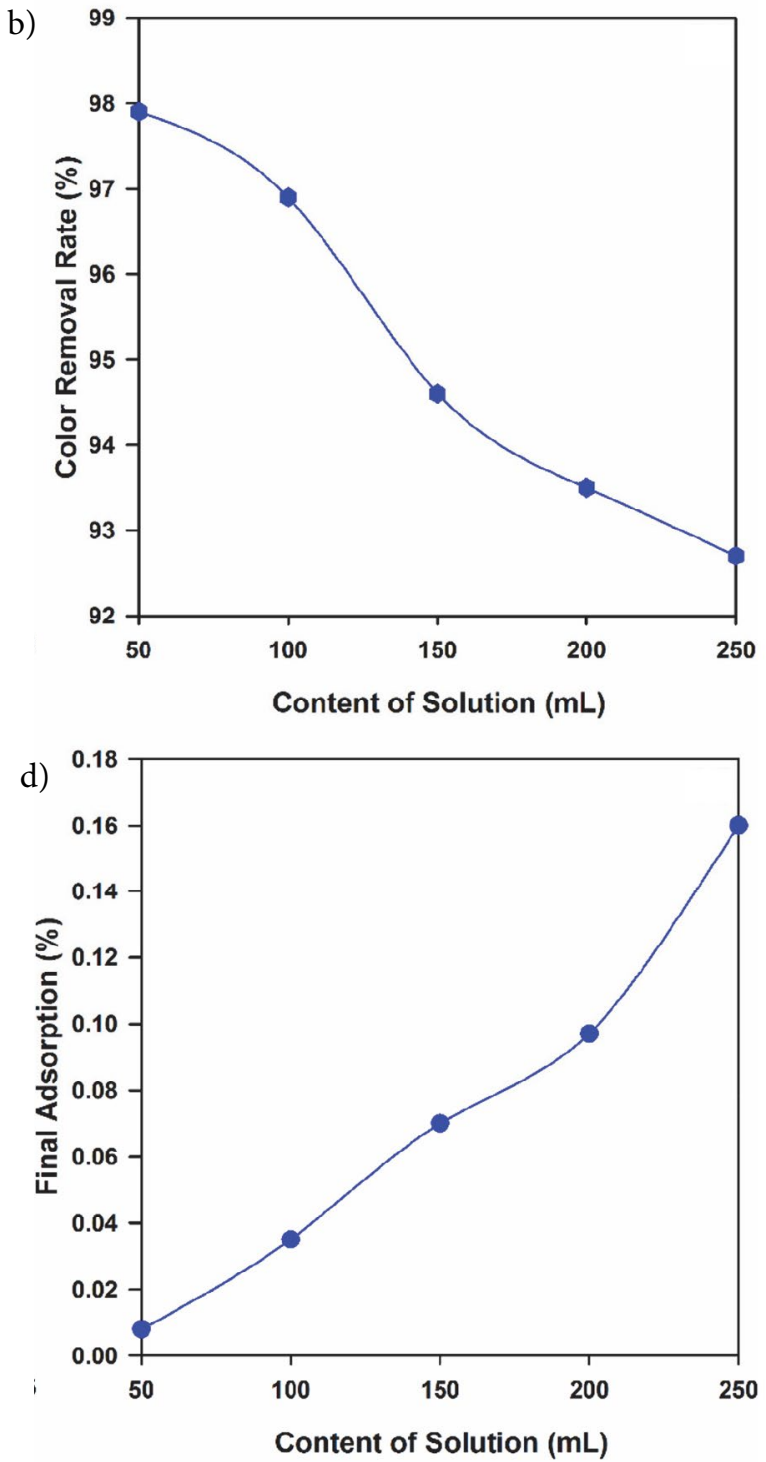

Figure 5. The effect of variable (a) electrolyte concentration and (b) solution content on the dye removal rate; and the effect of (c) electrolyte concentration and (d) solution content on the final adsorption rate of Erythrosine dye. 
sorption rate. Moreover, addition of electrolyte to the suspension containing absorber and dye neutralizing the surface of the absorber that can furtherly decrease the absorption of dye molecules by the absorber's surface. On the other hand, electrolyte can lead to decrease in the ionization of dye molecules. This process ease the extraction of non-ionic compositions and leads to higher absorption of neutral dye molecules compared with ionic molecules with whether positive or negative charges.

\section{2. 6. Effect of Solution Content on the Erythrosine Removal Rate}

In this section, various volumes of solution (ranging from $50-250 \mathrm{~mL}$ ) containing $1500 \mu \mathrm{g}$ Erythrosine dye were examined to evaluate the effect of solution content on the dye removal rate and final adsorption of Erythrosine dye, which can be seen in Fig. 5 (b) and (d), respectively. Achieved results showed that increase in the solution content to more than $100 \mathrm{~mL}$ can lead to significant decrease in the percentage of dye removal rate and final adsorption. Furthermore, the maximum dye removal rate was observed at $50 \mathrm{~mL}$ solution volume.

\section{2. 7. Effect of Temperature on the Erythrosine Removal Rate}

In this section, effect of variable temperature (ranging from 5 to $60^{\circ} \mathrm{C}$ ) on the dye removal rate and the final adsorption of Erythrosine dye from aqueous solution was examined. A view of these results can be seen in Fig. 6 (a) and (b), respectively. Obtained results showed that increase in the temperature to more than $15^{\circ} \mathrm{C}$ can highly enhance and improve the final dye removal rate.

a)

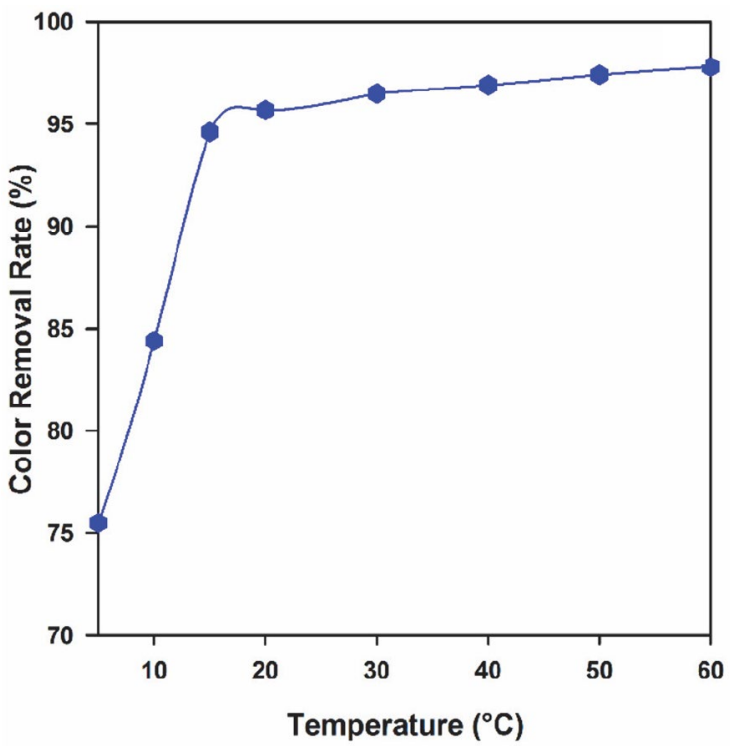

\section{3. Isotherm of Adsorption Process}

In this section, adsorption performance of developed $\mathrm{GO}-\mathrm{Fe}_{3} \mathrm{O}_{4}$ nanoparticles was described through isotherm. In this case, distribution of metal ions between both liquid and solid phases were examined using Langmuir and Freundlich isotherm models via obtained results from experimental data.

In this regard, for examination of adsorption process isotherm by developed adsorbents, different solutions containing various amount of Erythrosine dye (30, 35 and $40 \mu \mathrm{g} \mathrm{mL}-1$ ) were poured into a $50 \mathrm{~mL}$ volumetric flask along with $2 \mathrm{~mL}$ PBS ( $\mathrm{pH}=7$ ). Afterward, each prepared solution was added to several beakers and then $0.2 \mathrm{~g}$ GO$\mathrm{Fe}_{3} \mathrm{O}_{4}$ was added to each beaker. Thence, the resulting suspension was stirred for $150 \mathrm{~s}$ and placed on a strong magnet for further sediment of fillers. Thereafter, adsorption rate of each prepared sample was evaluated at wavelength of $523 \mathrm{~nm}$. Obtained data from experimental evaluation can be seen in Fig. 7 (a).

What is more, the Langmuir isotherm consider monolayer adsorption for a surface which containing a finite number of adsorption sites of uniform strategies without transmigration of adsorbate in the plane surface, ${ }^{29-31}$ which is defined as follow:

$$
\frac{C_{e}}{q_{e}}=\frac{1}{b q_{\max }}+\frac{C_{e}}{q_{\max }}
$$

Where $\mathrm{C}_{\mathrm{e}} / \mathrm{q}_{\mathrm{e}}, \mathrm{C}_{\mathrm{e}}$, constant $\mathrm{b}$ and $\mathrm{q}_{\max }$ are the specification of adsorption, equilibrium concentration, maximum adsorption capacity and energy of adsorption, respectively. The liner plot of the adsorption specification $\left(\mathrm{C}_{\mathrm{e}} / \mathrm{q}_{\mathrm{e}}\right)$ versus the equilibrium concentration $\left(\mathrm{C}_{\mathrm{e}}\right)$ can be

b)

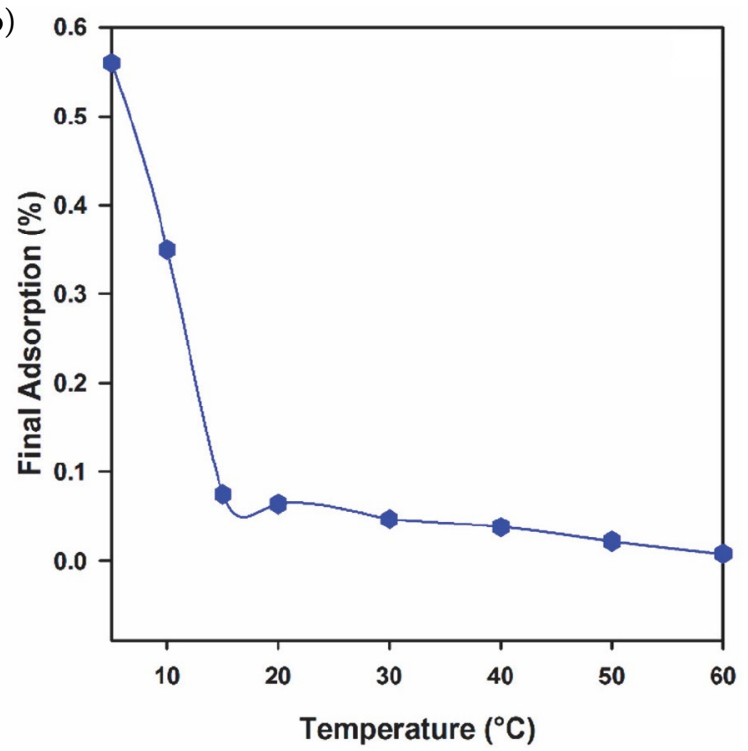

Figure 6. The effect of variable temperature on the (a) dye removal rate and (b) final adsorption of the Erythrosine dye. 
seen in Fig. 7 (b). Obtained results show that Langmuir isotherm model is perfectly compatible with experimental data. On the other hand, the Freundlich isotherm is an empirical model which can be defined as follows. ${ }^{32}$

$$
q_{e}=K_{f} C_{e}^{1 / n}
$$

Where $q_{e}, C_{e}, K_{f}$ and $n$ are the amount of adsorbed per amount of adsorbent at the equilibrium $(\mathrm{mg} / \mathrm{g})$, equilibrium concentration $(\mathrm{mg} / \mathrm{L})$, parameters that depend on the adsorbate and parameters that depend on the adsorbent, respectively. Mentioned equation ca be linearized and temperature dependence parameters such as $K_{f}$ and $1 / n$ can be transformed into the liner form as follows: ${ }^{33}$

$$
\ln q_{e}=\ln K_{f}+\frac{1}{n} \ln C_{e}
$$

Where $K_{f}$ and $\mathrm{n}$ are the Freundlich constants based on the adsorption capacity and intensity, respectively. Freundlich equilibrium constants can be determined from plot of against, which can be seen in Fig. 7 (c). Achieved results from both Langmuir and Freundlich isotherm models shows that the experimental data are more compatible with Langmuir model than Freundlich model. Moreover, the related equations for Langmuir and Freundlich are as follow:

$$
\begin{aligned}
& Y=0.0067 X+0.0072 \text { and } R^{2}=0.9982 \\
& Y=0.1791 X+1.9355 \text { and } R^{2}=0.9734
\end{aligned}
$$

In addition, obtained results from both experimental evaluation and simulation via Langmuir and Freundlich isotherm models indicated that increase in the concentration of adsorbent can lead to significant improvement in the final adsorption rate. Additionally, smaller correlation coefficient $\left(R^{2}\right)$ of Freundlich isotherm than Langmuir isotherm shows that the Langmuir isotherm model is proper to predict the behavior of adsorption process. It also shows that the adsorption of dye on the adsorbent is monolayer. Additionally, the maximum adsorption capacity obtained by Langmuir isotherm model was obtained at $149.25 \mathrm{mg} / \mathrm{g}$ which is a considerable amount.
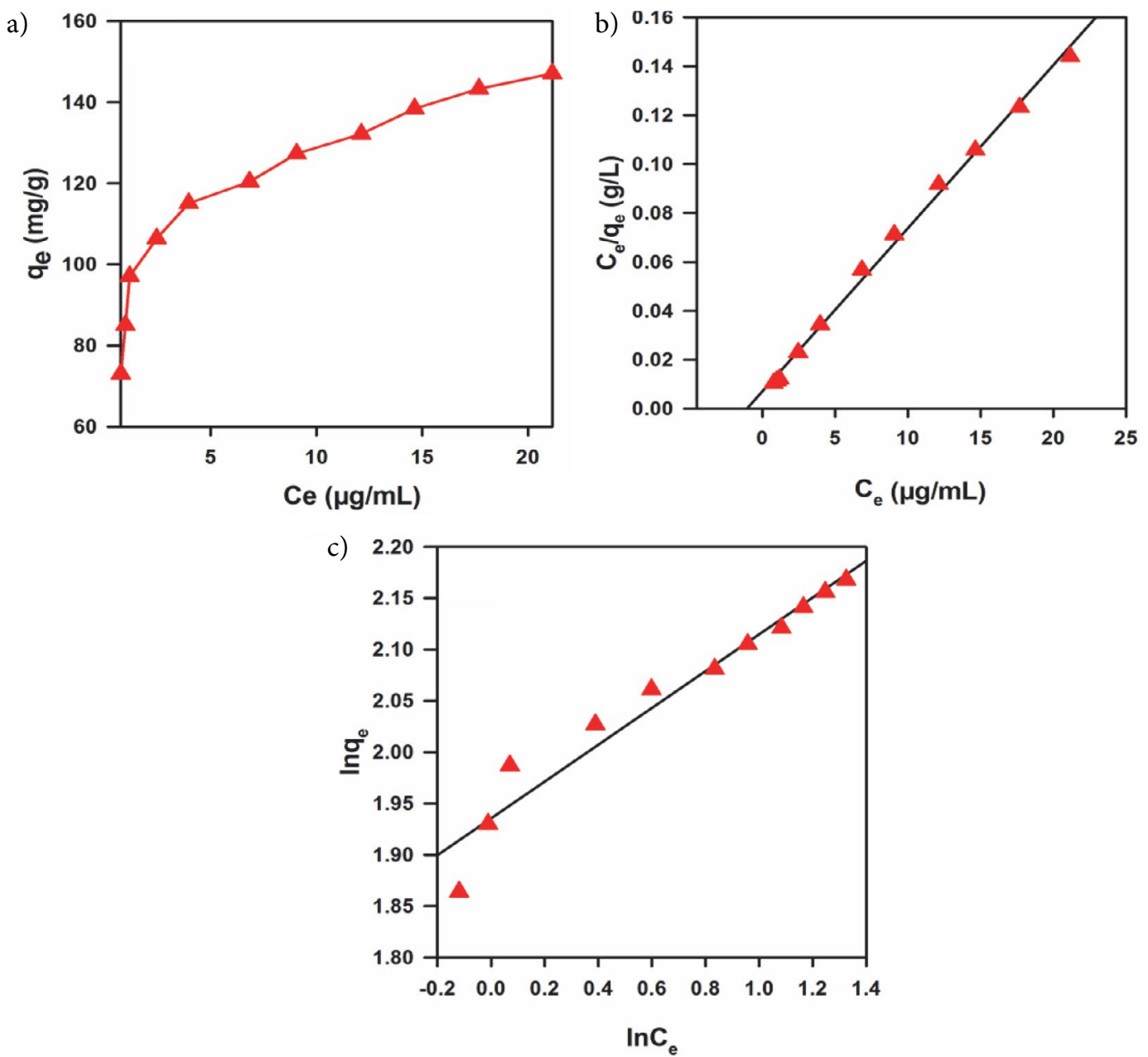

Figure 7. Adsorption isotherm of Erythrosine dye from aqueous solution obtained from (a) experimental evaluation, (b) Langmuir isotherm model and (c) Freundlich isotherm model. 


\section{3. 1. Kinetic Study of the Adsorption Process}

In this section, the kinetic of $\mathrm{GO}-\mathrm{Fe}_{3} \mathrm{O}_{4}$ adsorption process was examined at variable time ranging from 0.5 to $3.5 \mathrm{~min}$. Figure 8 (a), indicating that the adsorption process reached the balanced situation after $2.5 \mathrm{~min}$, while increase in the concentration of adsorbent can highly improve the adsorption rate. Furthermore, adsorption process of Erythrosine dye via $\mathrm{GO}-\mathrm{Fe}_{3} \mathrm{O}_{4}$ was also examined using the pseudo-first order equation (Figure 8 (b)) and pseudo-second order equation (Figure 8 (c)). ${ }^{34,35}$ According to the correlation coefficient of these two models, the dye adsorption process follows both pseudo-first order model and pseudo-second order equations; however, the pseudo-second order model is much more compatible with the experimental outcomes than the pseudo-first order model, which indicate the mechanism of chemical adsorption. The obtained line equations via these models and the correlation coefficients are as follow:

$$
\begin{aligned}
& \begin{array}{l}
30 \mu \mathrm{g} \mathrm{mL} \\
r
\end{array} \rightarrow \log \left(q_{e}-q_{t}\right)=-1.5614 t+2.4655, \\
& r=0.9753 \\
& 35 \mu \mathrm{g} \mathrm{mL}{ }^{-1} \rightarrow \log \left(q_{e}-q_{t}\right)=-1.1282 t+2.134, \\
& r=0.9941
\end{aligned}
$$

a)

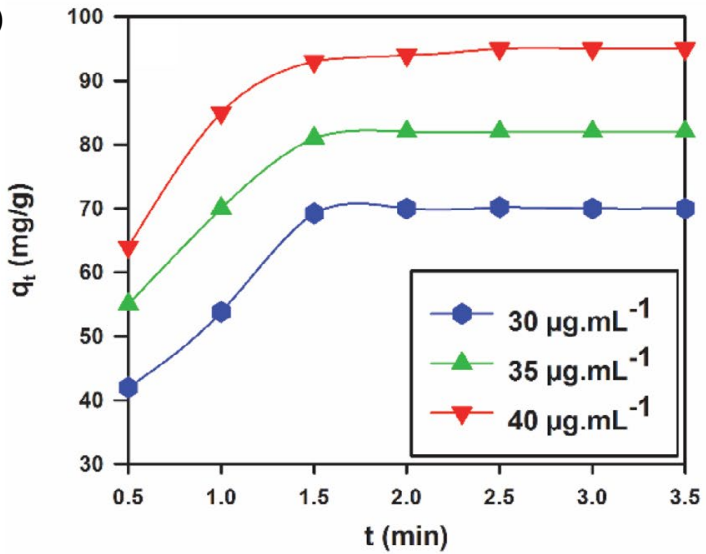

c)

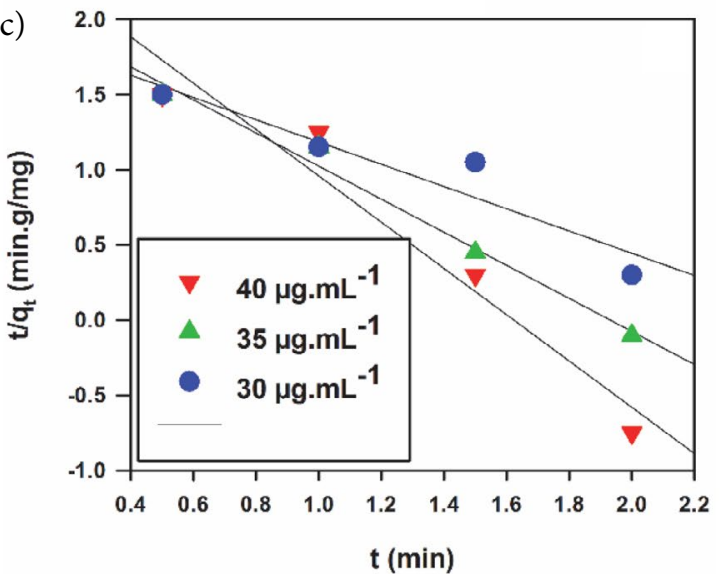

$40 \mu \mathrm{g} \mathrm{mL} \mathrm{m}^{-1} \rightarrow \log \left(q_{e}-q_{t}\right)=-0.8352 t+2.002$, $r=0.9602$

In addition, in order to examine the kinetic based on the pseudo-second order model, the diagram of $t / q_{t}$ changes was illustrated based on $t$, which can be seen in Fig. 8 (c). The obtained line equations and the correlation coefficients are as follow:

$$
\begin{aligned}
& 30 \mu \mathrm{g} \mathrm{mL}^{-1} \rightarrow t / q_{t}=0.01 t+0.0067, R^{2}=0.9918 \\
& 35 \mu \mathrm{g} \mathrm{mL}-1 \rightarrow t / q_{t}=0.0092 t+0.0045 \\
& R^{2}=0.9990
\end{aligned}
$$

$40 \mu \mathrm{g} \mathrm{mL}-1 \rightarrow t / q_{t}=0.0086 t+0.003$, $R^{2}=0.9984$

\section{4. Performance of Fillers for Removal of Erythrosine dye From Real Samples}

In this section, performance of developed GO$\mathrm{Fe}_{3} \mathrm{O}_{4}$ nanoparticles for removal of Erythrosine dye from real samples obtained from chicken slaughterhouse and hospital sewage disposal system was evaluated. In this
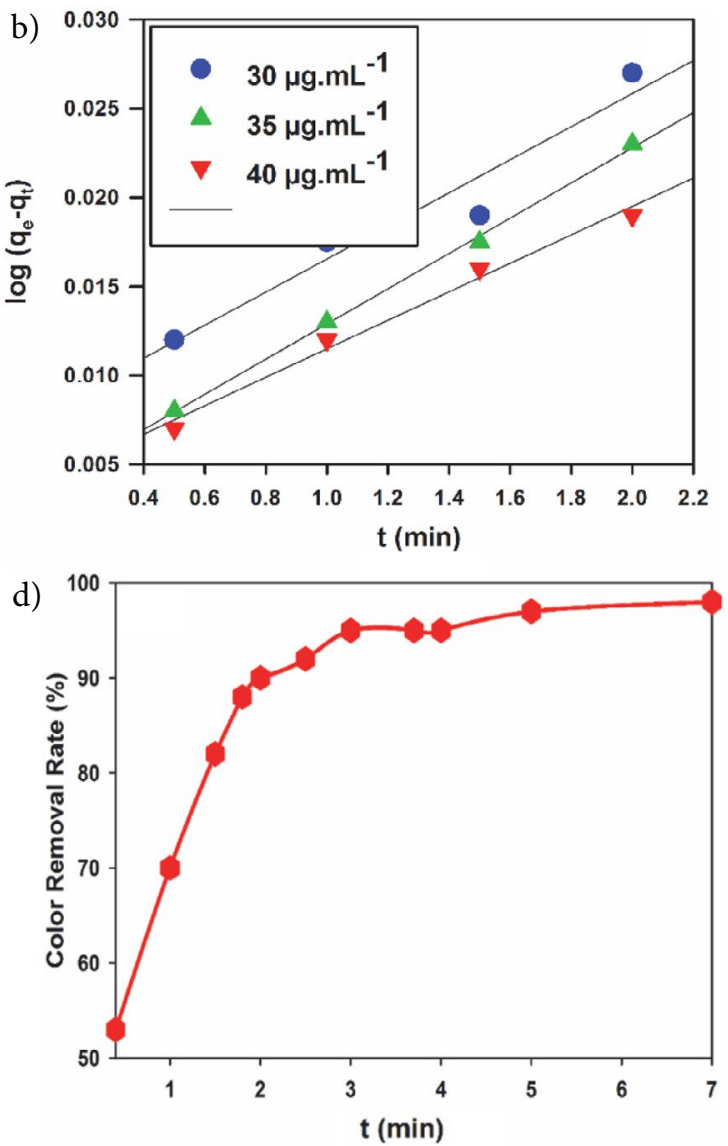

Figure 8. (a) The effect of the contact time and the concentration of Erythrosine dye solutions on the adsorption rate of the Erythrosine by the adsorbent, (b) The examination of the kinetic based on the pseudo-first order model and (c) The examination of the kinetic based on the pseudo-second order model (d) Average dye removal rate of Erythrosine dye from real samples obtained from chicken slaughterhouse and hospital. 
Table 1. Adsorption of Erythrosine dye from chicken slaughterhouse and hospital wastewaters.

\begin{tabular}{cccc}
\hline Sample & $\begin{array}{c}\text { Added dye } \\
\left(\mathbf{m g ~ m} \mathbf{~}^{-\mathbf{1}}\right)\end{array}$ & $\begin{array}{c}\text { Adsorbed dye } \\
\left(\mathbf{m g ~ m} \mathbf{~}^{-\mathbf{1}}\right)\end{array}$ & $\begin{array}{c}\text { Adsorption } \\
\mathbf{( \% )}\end{array}$ \\
\hline $\begin{array}{c}\text { Chicken } \\
\text { slaughterhouse }\end{array}$ & 20 & 16 & 94 \\
wastewater & 70 & 47.75 & 95.5 \\
\hline Hospital & 20 & 67 & 96 \\
wastewater & 50 & 18 & 96 \\
& 70 & 49 & 97 \\
\hline
\end{tabular}

case, various concentrations of Erythrosine dye (20, 50 and $70 \mathrm{mg} \mathrm{mL}^{-1}$ ) were added to two real samples that were obtained from chicken slaughterhouse and hospital, respectively, and thence the adsorption rate of dye via magnetic fillers was investigated. For this matter, in two turns, $0.2,0.5$ and $0.7 \mathrm{~mL}$ of Erythrosine dye $\left(10 \mu \mathrm{g} \mathrm{mL}^{-1}\right)$ was added to two different volumetric flasks, respectively, which were filled with wastewater obtained from chicken slaughterhouse and hospital, respectively. Then, prepared solutions were passed through an adsorbent pillar, while the washing action was performed with $2 \mathrm{~mL}$ of 2 molar ammonia $\left(\mathrm{NH}_{3}\right)$ buffer $(\mathrm{pH}=7)$. Afterward, the adsorption rate was measured at wavelength of $523 \mathrm{~nm}$ using UV-vis spectrophotometer. Achieved results can be seen in Table 1 and Fig. 8 (d). Calculated data within the Table 1 was measured based on the method that explained in the section 2.6.

Furthermore, one of the most important parts of an adsorption study is to investigate the possible disturbance role of each ion during the adsorption process, which could be used to develop the research for real samples. By evaluation of possible disturbance factors, we can figured out whether a method is practical or not. In this regard, possible disturbance effect of various kinds of cations and anions were investigated. If a considered ion create more than $5 \%$ systematic error during the calculation, we consider that ion as the annoying ion which should be removed from the system. In order to examine the current adsorption process, $1 \mathrm{~mL}$ of Erythrosine dye $\left(5 \mu \mathrm{g} \mathrm{mL}{ }^{-1}\right)$ was added to a volumetric flask, while the $\mathrm{pH}$ was set on 7 . Thereafter, various amount of annoying ions were poured into a $100 \mathrm{~mL}$ beaker and then the beaker was filled with

Table 2. Disturbance effect of various kinds of ions during the adsorption process.

\begin{tabular}{cc}
\hline $\begin{array}{c}\text { Concentration of } \\
\text { Ion or dye }(\mathbf{m g} / \mathbf{m L})\end{array}$ & Annoying kind \\
\hline 1500 & $\mathrm{~S}_{2} \mathrm{O}_{3}{ }^{2-}, \mathrm{C}_{2} \mathrm{O}_{4}{ }^{2-}, \mathrm{F}^{-}, \mathrm{Cl}^{-}, \mathrm{Br}^{-}$ \\
& $\mathrm{I}^{-}, \mathrm{Pb}^{2+}, \mathrm{Zn}^{2+}, \mathrm{Hg}^{2+-}, \mathrm{Na}^{+}$ \\
500 & $\mathrm{Cu}^{2+}, \mathrm{K}^{+}, \mathrm{Mn}^{2+}, \mathrm{Mg}^{2+}, \mathrm{NO}_{3}^{-}, \mathrm{Cr}^{3+}$ \\
& $\mathrm{CO}_{3}{ }^{2-}, \mathrm{HCO}_{3}{ }^{-}, \mathrm{Ni}^{2+}, \mathrm{Ca}^{2+}, \mathrm{Fe}^{3+}, \mathrm{Fe}^{2+}$ \\
\hline
\end{tabular}

deionized water. Thence, via vacuum pump, each solution was passed through a pillar containing $0.1 \mathrm{~g}$ of adsorbent. List of annoying kinds during the process can be seen in the Table 2.

Besides, in order to evaluate the standard deviation and repeatability of current method, the limit of detection (LOD) and relative standard deviations (RSD) were measured, respectively. The standard deviation can be calculated via the following equation:

$$
S_{b}=\sqrt{\sum_{i=1}^{n} \frac{\left(X_{i}-\bar{X}\right)^{2}}{n-1}}
$$

Where the calculated $S_{b}$ and $\bar{X}$ are 5.67 and 0.0071 , respectively. On the other hand, $L O D$ can be measured via the following formula:

$$
L O D=\frac{K S_{b}}{m}
$$

Where $\mathrm{K}, \mathrm{m}$ and $\mathrm{S}_{\mathrm{b}}$ are constant factor with value 3 , standard curve slop and standard deviation, respectively. The measured value of LOD was determined to be $1.82 \mathrm{mg}$ $\mathrm{mL}^{-1}$. In addition, in order to evaluate the repeatability of the adsorption procedure, the final adsorption of solutions containing 100 and $250 \mathrm{mg} \mathrm{mL}^{-1}$ Erythrosine dye were re-

Table 3. Results of repeatability at concentration $100 \mathrm{mg} \mathrm{mL}^{-1}$.

\begin{tabular}{ccc}
\hline Number & $\begin{array}{c}\text { Adsorption } \\
\mathbf{( \% )}\end{array}$ & $\begin{array}{c}\text { Concentration } \\
\left(\mathbf{m g ~ m} \mathbf{~ L}^{\mathbf{- 1}}\right)\end{array}$ \\
\hline 1 & 0.048 & 45.28 \\
2 & 0.048 & 45.28 \\
3 & 0.050 & 47.43 \\
4 & 0.050 & 47.43 \\
5 & 0.050 & 47.43 \\
6 & 0.048 & 45.28 \\
7 & 0.048 & 45.28 \\
8 & 0.050 & 47.43 \\
9 & 0.049 & 46.35 \\
10 & 0.048 & 45.28 \\
\hline
\end{tabular}

Table 4. Results of repeatability at concentration $250 \mathrm{mg} \cdot \mathrm{mL}^{-1}$.

\begin{tabular}{ccc}
\hline Number & $\begin{array}{c}\text { Adsorption } \\
(\mathbf{\%})\end{array}$ & $\begin{array}{c}\text { Concentration } \\
\left(\mathbf{m g ~ m} \mathbf{~ L}^{-\mathbf{1}}\right)\end{array}$ \\
\hline 1 & 0.242 & 252.99 \\
2 & 0.277 & 232.78 \\
3 & 0.262 & 274.44 \\
4 & 0.258 & 270.12 \\
5 & 0.255 & 266.91 \\
6 & 0.250 & 261.56 \\
7 & 0.244 & 255.13 \\
8 & 0.239 & 249.78 \\
9 & 0.240 & 250.85 \\
10 & 0.250 & 261.56 \\
\hline
\end{tabular}


peated for ten times and then measured with respect to the line equation of various concentrations. Obtained results for 100 and $250 \mathrm{mg} \mathrm{mL}^{-1}$ concentrations can be seen in the Tables 3 and 4, respectively, while the RSD for concentrations 100 and $250 \mathrm{mg} \mathrm{mL}^{-1}$ was determined to be 2.3 and $4.79 \%$, respectively. In this case, all of absorption rates were calculated based on the procedure that mentioned in section 2.6.

\section{Conclusions}

In this study, GO was fabricated via modified Hummers method and thence decorated with magnetite nanoparticles $\left(\mathrm{Fe}_{3} \mathrm{O}_{4}\right)$ through a multi-step manufacturing procedure. Thence, fabricated $\mathrm{GO}-\mathrm{Fe}_{3} \mathrm{O}_{4}$ nanoparticles were evaluated using FTIR, XRD, VSM and SEM analyses, and these analyses confirmed the successful synthesize of $\mathrm{GO}-\mathrm{Fe}_{3} \mathrm{O}_{4}$ and their fantastic magnetic properties. Thereafter, performance of developed fillers for the removal of Erythrosine dye from aqueous solutions under variable conditions and at variety of concentrations were examined and studied. Afterward, obtained experimental outcomes were used to evaluate the adsorption isotherm and kinetic of GO- $\mathrm{Fe}_{3} \mathrm{O}_{4}$ nanoparticles. Finally, performance of developed magnetic nanoparticles for the removal of Erythrosine dye from real samples obtained from chicken slaughterhouse and hospital sewerage disposal system were investigated. Achieved results revealed the fantastic performance of $\mathrm{GO}-\mathrm{Fe}_{3} \mathrm{O}_{4}$ nanoparticles for removal of Erythrosine dye from various kinds of aqueous solutions under variety of conditions.

\section{Funding}

This research did not receive any specific grant from funding agencies in the public, commercial, or not-forprofit sectors

\section{Conflicts of Interest}

The authors declare that they have no conflicts of interest.

\section{References}

1. R. Bernstein, H. Haugen and H. Frey, Scandinavian journal of clinical and laboratory investigation 1975, 35, 49-52.

DOI:10.3109/00365517509068004

2. S. Bonan, G. Fedrizzi, S. Menotta and C. Elisabetta, Dyes and Pigments 2013, 99, 36-40. DOI:10.1016/j.dyepig.2013.03.029

3. E. V. Hess, Toxicology 2002, 181, 65-70.

4. I. Poulios, D. Makri and X. Prohaska, Global Nest: Int. J 1999, $1,55-62$.
5. Y. Ho and G. McKay, Process safety and environmental protection 1998, 76, 313-318. DOI:10.1205/095758298529678

6. I. El-Thalouth, M. Kamel, K. Haggag and M. El-Zawahry, American Dyestuff Reporter 1993, 82, 36-36.

7. J. A. Laszlo, American Dyestuff Reporter 1994, 83, 5.

8. L. Morais, O. Freitas, E. Goncalves, L. Vasconcelos and C. G. Beca, Water Research 1999, 33, 979-988.

DOI:10.1016/S0043-1354(98)00294-2

9. M. Hasnat, I. Siddiquey and I. S. Saiful, 2003.

10. J. I. Álvarez-Uriarte, U. Iriarte-Velasco, N. Chimeno-Alanís and J. R. González-Velasco, Separation Science and Technology 2011, 46, 2239-2249.

DOI:10.1080/01496395.2011.594847

11. R. Jain and S. Sikarwar, Journal of hazardous materials 2009, 164, 627-633. DOI:10.1016/j.jhazmat.2008.08.043

12. Y. TONOGAI, M. IWAIDA, M. TATI, Y. OSE and T. SATO, The Journal of toxicological sciences 1978, 3, 205-214.

13. Z. Hu and M. Srinivasan, Microporous and Mesoporous Materials 2001, 43, 267-275. DOI:10.1016/S1387-1811(00)00355-3

14. Z. Jin, X. Wang, Y. Sun, Y. Ai and X. Wang, Environmental science \& technology 2015, 49, 9168-9175.

DOI:10.1021/acs.est.5b02022

15. S. Yu, X. Wang, Y. Ai, X. Tan, T. Hayat, W. Hu and X. Wang, Journal of Materials Chemistry A 2016, 4, 5654-5662. DOI:10.1039/C6TA00890A

16. G. Zhao, L. Jiang, Y. He, J. Li, H. Dong, X. Wang and W. Hu, Advanced materials 2011, 23, 3959-3963.

DOI:10.1002/adma.201101007

17. Y. S. Al-Degs, R. Abu-El-Halawa and S. S. Abu-Alrub, Chemical engineering journal 2012, 191, 185-194.

DOI:10.1016/j.cej.2012.03.002

18. S. M. Mousavi, S. A. Hashemi, A. M. Amani, H. Esmaeili, Y. Ghasemi, A. Babapoor, F. Mojoudi and O. Arjomand, Physical Chemistry Research 2018, 6, 759-771.

19. S. M. Mousavi, S. A. Hashemi, H. Esmaeili, A. M. Amani and F. Mojoudi, Acta Chimica Slovenica 2018.

20. S. A. Hashemi, S. M. Mousavi, R. Faghihi, M. Arjmand, S. Sina and A. M. Amani, Radiation Physics and Chemistry 2018, 146, 77-85. DOI:10.1016/j.radphyschem.2018.01.008

21. S. M. Mousavi, S. A. Hashemi, M. Arjmand, A. M. Amani, F. Sharif and S. Jahandideh, ChemistrySelect 2018, 3, 72007207. DOI:10.1002/slct.201800996

22. F. S. Khoo and H. Esmaeili, J. Serb. Chem. Soc. 2018, 83, $237-$ 249.

23. F. Entezari Juybari, A. Kamran-Pirzaman and M. Ghorbani, Inorganic and Nano-Metal Chemistry 2017, 47, 121-126. DOI:10.1080/15533174.2016.1149733

24. Y. Wei, B. Han, X. Hu, Y. Lin, X. Wang and X. Deng, Procedia Engineering 2012, 27, 632-637. DOI:10.1016/j.proeng.2011.12.498

25. S. Baharin, N. Muhamad Sarih and S. Mohamad, Polymers 2016, 8, 117. DOI:10.3390/polym 8050117

26. G. Xie, P. Xi, H. Liu, F. Chen, L. Huang, Y. Shi, F. Hou, Z. Zeng, C. Shao and J. Wang, Journal of Materials Chemistry 2012, 22, 1033-1039. DOI:10.1039/C1JM13433G 
27. J. Hur, J. Shin, J. Yoo and Y.-S. Seo, The Scientific World Journal 2015, 2015.

28. L. Ai, C. Zhang and Z. Chen, Journal of hazardous materials 2011, 192, 1515-1524. DOI:10.1016/j.jhazmat.2011.06.068

29. M. B. Desta, Journal of thermodynamics 2013, 2013.

30. B. Hameed, A. M. Din and A. Ahmad, Journal of hazardous materials 2007, 141, 819-825.

DOI:10.1016/j.jhazmat.2006.07.049

31. S. Mohammad Beigi, A. Babapoor, V. Maghsoodi, S. M. Mousavi and N. Rajabi, Iranian Journal of Chemistry and Chemical Engineering (IJCCE) 2009, 28, 81-89.
32. A. Teimouri, H. Esmaeili, R. Foroutan and B. Ramavandi, Korean Journal of Chemical Engineering 2018, 35, 479-488. DOI:10.1007/s11814-017-0311-y

33. B. S. Zadeh, H. Esmaeili and R. Foroutan, Indonesian Journal of Chemistry, 18, 265-271.

34. W. Rudzinski and W. Plazinski, Adsorption 2009, 15, 181. DOI:10.1007/s10450-009-9167-8

35. X. Li, Y. Liu, C. Zhang, T. Wen, L. Zhuang, X. Wang, G. Song, D. Chen, Y. Ai and T. Hayat, Chemical Engineering Journal 2018, 336, 241-252. DOI:10.1016/j.cej.2017.11.188

\section{Povzetek}

$\mathrm{V}$ tej raziskavi smo s pomočjo modificirane Hummersove metode sintetizirali grafen oksid (GO), ki smo mu nato $\mathrm{v}$ večstopenjskem postopku površino modificirali $\mathrm{z}$ nanodelci $\mathrm{Fe}_{3} \mathrm{O}_{4}\left(\mathrm{GO}-\mathrm{Fe}_{3} \mathrm{O}_{4}\right)$. Material smo karakterizirali $\mathrm{z}$ naslednjimi metodami: infrardečo spektroskopijo (FTIR), rentgensko praškovno difrakcijo (XRD) in vrstično elektronsko mikroskopijo (SEM). Magnetne lastnosti materiala smo preučili z merilnikom namagnetenosti s tresočim se vzorcem (VSM). Preučevali smo tudi učinkovitost $\mathrm{GO}-\mathrm{Fe}_{3} \mathrm{O}_{4}$ za odstranjevanje in adsorpcijo barvila eritrozin iz vodne raztopine pod različnimi pogoji kot so: pH, dodatek fosfatnega pufra (PBS), vsebnost adsorbenta, čas mešanja, koncentracija elektrolita in temperatura. Za ta del raziskav smo uporabili vzorce iz sistema za odstranjevanje odplak v obratu piščančje klavnice in bolnišnice, ki so vsebovali 20,50 in $70 \mathrm{mg} / \mathrm{ml}$ barvila eritrozin. Od $94 \%$ do 97 \% celotnega barvila smo uspeli adsorbirati z uporabo nanodelcev $\mathrm{GO}-\mathrm{Fe}_{3} \mathrm{O}_{4}$. Najvišjo adsorpcijsko zmogljivost smo določili s pomočjo Langmuirjevega modela in je znašala $149,25 \mathrm{mg} / \mathrm{g}$. Dobljeni rezultati so jasno pokazali so nanodelci $\mathrm{GO}-\mathrm{Fe}_{3} \mathrm{O}_{4}$ primerni za absorpcijo in odstranjevanje barvil iz odplak. 